\title{
ため池の特性と都市用水への利活用
}

\author{
西山壯一 ${ }^{1}$

\section{Characteristics of Irrigation Reservoir in Urban Area and Water Use in District}

Soichi Nishiyama ${ }^{1}$

\section{1 まえがき}

ため池の水を他の用水に転用することを論じたものではな く,ここではため池を農業者以外の地域住民と管理する場 合の一形態について論じたものである.

近年ため池の管理については, 粗放化が進行しつつあ るといわれている。その理由は, 農業者の減少および高齢 化, 経済の高度成長に伴う労賃の高騰であると考えられる。 寸なわち，ため池の草刚を行っても，経済的に割に合わ なくなったためであると考えられる.たとえば各農家に牛馬 がいる時代はともかく, 刚った草の利用価值がなくなって いる.ため池は, 農業の水源として重要なものであり, 今後 も管理していく必要がある. 管理に地域の方々が参加して いただける論理の1つとして,ため池の果たす公益的機能 である多面的機能がある.もちろん, 食糧生産すること自 体が公益的な機能を持つと考えることもできる.

そこで，ため池の果たす多面的機能を今一度考えなが ら、地域住民の方々が積極的に参加が期待できると思わ れることを考えてみたい。

したがって,ここでは農業用水を他の用水に変更して， その使用を議論するのでなく, 農業を行いながら農業者 以外の人も十分目に見えた形でため池の恩恵にあずかる 方式を考えてみたい.また, 一般の住民からため池がさら に親しまれるためにはどんなことを解決する必要があるか を大まかに論じている.

\section{2 ため池の多面的機能}

ため池県の代表である香川県のため池の例を述べる. 香 川県はいわゆる瀬戸内海気候に属し, 日本でも有数の少 雨地帯である. そのため古来からため池が築造され, 現在 約1万5千のため池が存在し, ため池密度は全国一である. また, 灌泊用水のため池依存率も約 $50 \%$ で女り, 全国平 均約 $10 \%$ (香川県, 2003年)にくらべきわめて高い. ため池 はまた, 農業用水の貯水のみならず, 洪水の緩和など防 災にも役に立っている. 特に9月ごろ台風に伴う大雨がも たらす洪水の緩和効果は大きい. ちょうどそのころ稲は灌 溉が終わったかあるいは終わりがけでありため池の貯水率 が低くなっていて,ため池が防災の機能を発揮しやすくな っているのである.このような洪水の緩和によって, 人命,

${ }^{1}$ 山口大学農学部教授, Professor, Faculty of Agriculture, Yamaguchi University, 1677-1 Yoshida, Yamaguchi-shi, 753-8515 Japan
財産, 公共物などの安全性の確保はもちろんのこと, 下流 の水路や河川に住む水生生物にも適切な流速などの水 理環境が保たれている.また, ため池は水田とともに地下 水を涵養し, 下流の河川流量の安定に寄与しながら生物 の生息の場を広代環境保全にも役立っている.さらにため 池がもたらす湧水などがあるところに住む生物の保全に役 立っている.もちろん，ため池そのものにも多くの生物がい る.なかには，ため池のみしかいない生物もいる.このよう にため池は生物多様性にも貢献しているのである. 特に 周年水があることはその寄与が大きい。

ため池には周年水があるので特に中山間地において, ため池群として存在するとき, ため池, 水田, 水路, 山林な ぞが組み合わさり，環境に変化が生じる，そのことがため 池地域の生物多様性に寄与しているのである. 寸なおち, 中山間地にため池群として存在するとき, 単に水の存在に よって水生生物が増えるのみならず, 適度な距離にため 池が存在することによって, 環境に変化をもたらし, 生物 多様性がある.さらに, ため池近くでは, 井戸水を使い, た め池が地下水の涵養に寄与している.ため池近傍におい て,ため池から距離が離れるにしたがって, 地下水位が低 くなっていることは, ため池が地下水の涵養に寄与してい ることの好例である。

また,ため池は土の構造物でありさらに築造から数百年 過ぎ, 周りの景色と調和してその景観が地域の人に親しま れている.さらに, ため池の水は集落の近くでは防火用水 として使うこともでき,ため池の存在が地域の人々に安心 感を与えている。

香川用水通水後にも，取水はたびたび制限を受け，用 水としてのため池の重要性は認識されていたが, 中でも平 成6年には香川用水の水源である早明浦ダムの底が見え るぐらいの渇水となり,ため池保全の重要性の認識が高ま った. また, 平成7年には阪神大震災が起こり, 町は火事 となり都市に扔ける水のあり方が問われているようであった。 災害のときは, 水が必要なのである.さらに, 香川県のた め池は香川用水の調整池の役割を果たし(佐戸，1983), 香川用水の有效利用に寄与している.

以上のようにため池は農業用水はもちろんのこと，防災， 環境保全, 生物多梯性, 景観形成, 防火用水, 地下水涵 養など多方面に役立っている.ため池は, 永いのは千年 近く多くは数百年にわたり, 地域の人々によって営々と利 用·管理され、今日に至っているのである. 今後も, 地域の 
重要な資源あるいは財産として管理し, 後世に引き継が ねばならない。

\section{3 地域住民とのため池の共同管理による地下水利用}

さて，ため池近くに㧤いて，地下水を家庭用水として利用 する場合の解決寸心゙き主な課題について述心゙てみよう.

もちろん, 飲料水としての㛜密な水質検査が必要である ことは言うまでもない。

生物多様性を初めとして, 環境を保全することが人間に も良い環境となるが，その成果が出てくるのが時間が掛か り過ぎそのことが環境保全の重要性の理解が遅〈なってい るのではないかと考えるのである。環境保全を徹底的に行 えば, ため池近くの地下水は飲料水ししても, 適する可能 性は十分あると考えられる。

\section{1 集落排水処理施設などの必要性}

ため池の水質を水系毎に整理すると, 標高が低くなるにし たがって水質は悪くなっている(河野, 1996)。この原因は 家庭排水のため池への流人にあると考えられる.すなわち， 標高が低いほど，人間活動が活発でありそれに伴って， 排水が多くなっていると思われる.

標高の高い山のなかにはあまり人が住んでいない.した がって，排水も少ないものと考えられる.ため池地帯に拉 いては特に排水処理施設を設置して,ため池の水質を上 げる必要がある。

ため池の水を飲料水どころか，灌溉にも使えないところ もあると聞いている。

たとえば, 清浄野菜の灌泊については污れた水を灌溉 すれば, イメージが悪くなり，売り上げが低下寸る可能性も あろう.イチゴやレタスなど清浄野菜の灌溉には污れた水 の灌溉はイメージダウンとなろう.

すなわち，ため池近くの地下水を飲料水に利用寸る場 合，当然ながらそのため池の水が灌溉用として使えること が前提である。

家庭排水の存在によって, 生物多様性にも影響もあると 言われている。

\section{2 ヘドロの除去}

ため池の底にはへドロが堆積していて, 水のみ浄化しても へドロから污染物質が溶出する.したがって、水質保全の ためにはへドロを除去する必要がある.

ため池の数が多ければ, へドロの量は膨大なものである. したがって，その処理には相当の手数, 経済的負担が考
えられる.いずれ処理する必要があることを考えると早いう ちに，へドロが増加しない方策を講じる必要がある。また， その有効利用を考えねばならない、へドロの土をつかって， どんな作物にどの程度の効果があるか試験を行い，その 結果を冊子などにまとめ, 利用を呼びかけるのも一方法で ある.あるいは, 肥効しだいによっては商品となる可能性も 十分考えられる. むかしはため池を掃除して, へドロを水 田にいれ肥料としていたのである.しかしそれを知ってい ないひとが多くなっている.また，具体的にどんな作物に 効くかを明示すれば，わかりやすいのである.たとえば，大 豆を栽培したら，どのように収量が増えたか，あるいはへド 口を使った場合と使わない場合の生育途中の写真の比較 などをいれて，具体的に見ていただくなどが考えられる.

\section{3 ため池近傍地域での地下水の飲料水への利用}

水質検查を十分行いながら，人家からの排水のない山の 中のため池で, すでに以前から地下水を利用していた地 区で，その利用を搪大する，そのことによって，そのような 地区ではため池の管理がより容易になると考えられる.

\section{4 まとめ}

ため池を管理する場合の一形態について論じた。ため池 を含んだ地域の環境保全が地域の人々によ゙のような恩恵 をもたらすのか身近な形で示そうと考え, 地下水利用を思 いついたのである。すすおち, ため池保全の重要性は, 概 念的には理解されるが，ため池の保全についてその保全 が極めて身近にフイードバックがあるような例が必要では ないかと考えたのである。

たとえば，ダムの水を飲料水として，使っている住民は そのダムを污すようなことはしないであろうと思うのである。 幸いなことにため池は, 近くにあり, 農業用水, 飲料水など がそのため池の恩恵にあずかっていることになれば，地域 のため池の管理には十分参加していただき、ため池は大 切にされることと思うのである.

\section{引用文献}

［1］香川県農政水産部(2003): 香川県老朽ため池整備促進計 画、第8次5力年計画

［2］佐戸政直 (1983): 老朽ため池とその対策、農土誌51(7), pp. $587-601$

[3] 河野広 (1996):ため池の水質改善に関寸る研究、平成5年 度科学研究費補助金 (一般研究C) 研究成果報告 